\title{
Investigate the Ability of the Eggshell to Attenuate the Gamma and Beta Rays as Compared with Composite $\mathrm{FeSO}_{4 \cdot} \cdot \mathrm{H}_{2} \mathrm{O}$
}

\author{
Esraa Al-Sarray ${ }^{1, ~ *, ~ A l i ~ J a b b a r ² ~}$ \\ ${ }^{1}$ Directorate of Education, Iraqi Ministry of Education, Baghdad, Iraq \\ ${ }^{2}$ Directorate of Nuclear Research and Applications, Ministry of Science and Technology, Baghdad, Iraq \\ Email address: \\ esraa.alsaray@outlook.com (E. Al-Sarray) \\ ${ }^{*}$ Corresponding author
}

\section{To cite this article:}

Esraa Al-Sarray, Ali Jabbar. Investigate the Ability of the Eggshell to Attenuate the Gamma and Beta Rays as Compared with Composite $\mathrm{FeSO}_{4} .7 \mathrm{H}_{2} \mathrm{O}$. Nuclear Science. Vol. 3, No. 1, 2018, pp. 16-22. doi: 10.11648/j.ns.20180301.13

Received: January 12, 2018; Accepted: April 20, 2018; Published: May 17, 2018

\begin{abstract}
A hidden danger, no color and no taste for nuclear radiation that can have effects in human health While increasing the use of ionizing radiation The risk of health increases If is not used or contained correctly. And in order to avoid the risks of this radiation to the health of workers And clients With these radiations to look for a continuous and extensive search In all materials that can protect them from this radiation. These materials must be inherently harmless, with a low material cost. In this study, four samples were done with different mixing ratios for studying the attenuation coefficient of gamma rays and beta particles barriers made of polymer, epoxy, $\mathrm{FeSO}_{4} .7 \mathrm{H}_{2} \mathrm{O}$ compounds in addition to Eggshells and in certain proportions and the use of these samples measure the attenuation coefficient of gamma rays and beta particles using radioactive sources. (Caesium-137 and Strontium-90). At the end of this research the ability of Eggshells to attenuate beta particles and excelled $\mathrm{On} \mathrm{FeSO}_{4} \cdot 7 \mathrm{H}_{2} \mathrm{O}$ compounds. The gamma attenuation coefficient is very close to $\mathrm{FeSO}_{4} \cdot 7 \mathrm{H}_{2} \mathrm{O}$ compounds. These readings were taken at the Directorate of Treatment and Management of Iraqi Radioactive Waste based.
\end{abstract}

Keywords: Shields, Beta Radiation, Gamma Ray, Polymer, $\mathrm{FeSO}_{4} .7 \mathrm{H}_{2} \mathrm{O}$ Composites, Eggshells

\section{Introduction}

Human-induced radiation such as $\mathrm{x}$-rays, nuclear power plants may also occur in ionization smoke detectors. Radiation has an important role in purely scientific and applied scientific research. Even nuclear branches are specialized in many important fields such as physics, chemistry, [1] biology, and Earth sciences. The method of neutron-wide analysis has been widely used in periodic and modern experiments due to ease and finite detection On the effects of different elements in different liquid samples and solid and in determining their proportions. The focus in these years on the exploitation of radiation and its uses in various types of fields in medicine, especially hospitals, industry in the field currently used in generating electricity. [2] In order to avoid the dangers of these radiation on the health of workers, especially on the ionization of living cells of the human body, the subject of radiation protection is a major issue in how to create shields of hazardous radiation to which the worker is exposed. [3] this search will be limited to shielding from hazardous radiation that harms man and his environment if misused and if adequate prevention is not carried out using non-toxic, lightweight and materially inexpensive materials. In this experience has been used. Polymers Is a compound of high molecular weight due to its unique properties. Polymers are present in most soil, plant and organism components. [4] polymer compounds with organic material are important in nutrition, mechanical engineering, biology, medicine, computers, space exploration, health and the environment. Polymers consist of structures consisting of repeated identical structural units. These units in turn are made up of smaller molecules called monomers or monomers. The meridians interact with each other to form the polymer. Physical properties of polymers. Physical properties of polymers include polymerization and mass distribution. [5] Epoxy is a chemical that is a kind of thermoplastic polymers that are hardened when exposed to 
energy to move to a condition that is harder than its first state. by chemical reaction,. Epoxy material is highly adhesive and resistant to friction after dryness, forming as an insulating layer, The most common types of epoxy are the resin material resulting from the interaction between epichlorohydrin and bisphenol. [6] Melanterite is a chemical composition and its symbol $\left(\mathrm{FeSO}_{4} \cdot 7 \mathrm{H}_{2} \mathrm{O}\right)$ Melantrate is a wet iron sulfate formed after the degradation of barite or other iron minerals. [7] The decomposition factors are surface water, and is often present in the post-drilling and mining mines on the mine wall. Other iron (Sulphates) such as (Halutrichate) and (Yosemite) are predominant. [8] iron(II) sulphate) or ferrous sulfate Make it a mixture of salts with formula $\mathrm{FeSO}_{4} \cdot \mathrm{xH}_{2} \mathrm{O}$. And that such a composite exists more (heptahydrate) $(\mathrm{x}=7)$ And it is known for several values of $(\mathrm{x})$ is used in water form in medicine to treat iron deficiency, and also in industrial uses See Figure 1. since ancient times as copper and green soda, The most common form is (heptahydrate) blue and green. All the iron (II) sulfate dissolved in water to give the same aquo complex $\left[\mathrm{Fe}\left(\mathrm{H}_{2} \mathrm{O}\right)_{6}\right]^{2+}$, Which has a molecular geometry of eight surfaces (paramagnetic). The name (s) in earlier times were known as copper sulphate (II) and blue copper, Perhaps in symmetry iron and zinc sulphate were respectively green and white. [9] See Figure 1.

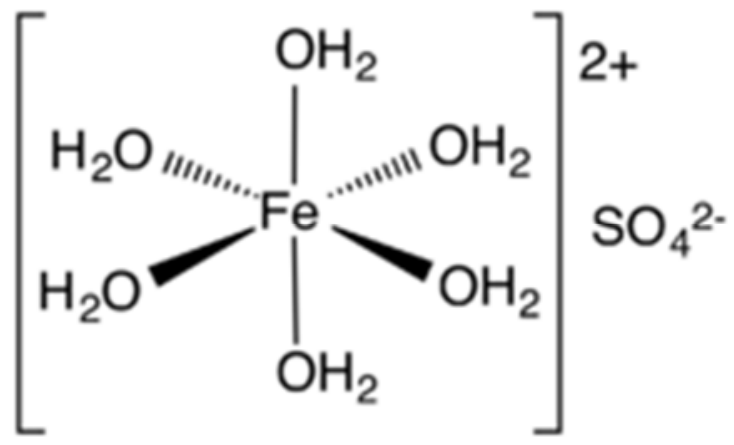

Figure 1. Iron(II) sulfate, when dissolved in water.

(Hydrates) The finding of iron sulfate (II) in the wet state and many of this form exist in nature.

a. $\mathrm{FeSO}_{4} \cdot \mathrm{H}_{2} \mathrm{O}$ (mineral: Szomolnokite, [10] relatively rare).

b. $\mathrm{FeSO}_{4} \cdot 4 \mathrm{H}_{2} \mathrm{O}$ (mineral: Rozenite, [11] white, relatively common, may be dehydratation product of melanterite).

c. $\mathrm{FeSO}_{4} \cdot 5 \mathrm{H}_{2} \mathrm{O}$ (mineral: Siderotil, [12] relatively rare).

d. $\mathrm{FeSO}_{4} \cdot 6 \mathrm{H}_{2} \mathrm{O}$ (mineral: Ferrohexahydrite, [13] relatively rare).

e. $\mathrm{FeSO}_{4} \cdot 7 \mathrm{H}_{2} \mathrm{O}$ (mineral: Melanterite, [14] blue-green, relatively common).

Four hydrates are installed at the temperature of the water solution. $56.6^{\circ} \mathrm{C}\left(133.9^{\circ} \mathrm{F}\right)$. At $64.8^{\circ} \mathrm{C}\left(148.6{ }^{\circ} \mathrm{F}\right)$. All mentioned mineral forms are connected with oxidation zones of iron-bearing ore beds (pyrite, marcasite, chalcopyrite, etc.) and related environments (like coal fire sites). Many undergo rapid dehydration and sometimes oxidation. See Figure 2.

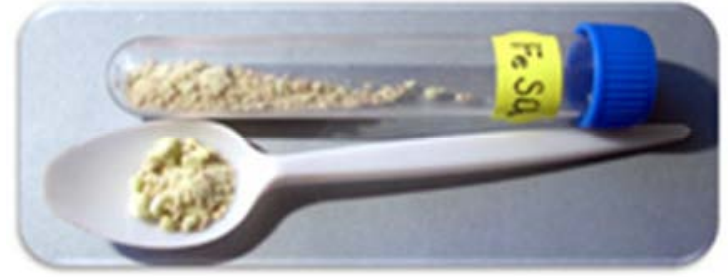

Figure 2. Anhydrous iron(II) sulfate.

Eggshells It is an amazingly useful material that the egg shells are $95-97 \%$ composed of crystalline carbonate crystals, [15] which is the permanence of protein matrix, and the absence of protein, crystalline structure will be very loose and will not be able to maintain its appearance and Belief that the organic matrix is mainly in sedimentation Calcium During the process of formation, chicken eggshells they produce a biological substance (hydroxyapatite) by a conventional chemical method is the deposition method (hydroxinate) is a key element of solid tissues of the human, such as (bone) and (teeth) as a biological active substance, In hydroxipa formation Tate is the switch from the main element calcium carbonate to the stage of calcium oxide in the degree Celsius (1000). [16] After that, calcium oxide is moistened to produce calcium hydroxide, followed by hydroxyapatite, phosphoric acid. Reuse of chicken eggshells reduces the amount of boost, as well as the need for biological waste management. The US food industry produces 150,000 tons of shell residues per year. [17] "Methods of disposal of egg husks are $26.6 \%$ as fertilizer, $21.1 \%$ as animal feed, $26.3 \%$ are excluded from landfills, and $15.8 \%$ are used in other ways". [18] " Many landfills are unwilling to take the waste because the shells and the attached membrane attract vermin". [19] This investigation shows that egg husks can be a useful raw. [20] material for the synthesis of valuable biomaterials. In this experiment the egg white shell was collected for chicken and dried and then gently grinded for use in the experiment.

\section{Materials and Methods}

In this study, the four samples using the polymer and epoxy compound as a major compound with a specific percentage of $\mathrm{FeSO}_{4} .7 \mathrm{H}_{2} \mathrm{O}$ and $100 \%$ egg shell, this means the total weights of the four samples were $200 \mathrm{gm}$. the first sample contain $90 \mathrm{gm}$ of polymer and $90 \mathrm{gm}$ of epoxy with $10 \mathrm{gm}$ of egg shells and $10 \mathrm{gm} \mathrm{FeSO}_{4} \cdot 7 \mathrm{H}_{2} \mathrm{O}$, the second sample $70 \mathrm{gm}$ of polymer and $70 \mathrm{gm}$ of epoxy with $30 \mathrm{gm}$ of eggshell and $30 \mathrm{gm} \mathrm{FeSO}_{4} \cdot 7 \mathrm{H}_{2} \mathrm{O}$, The third sample was only $75 \mathrm{gm}$ of epoxy $75 \mathrm{gm}$ of polymer with $50 \mathrm{gm}$ of egg shell only without $\mathrm{FeSO}_{4} .7 \mathrm{H}_{2} \mathrm{O}$, the fourth sample was $75 \mathrm{gm}$ of epoxy 75 gm of polymer with $50 \mathrm{mg} \mathrm{FeSO}_{4} .7 \mathrm{H}_{2} \mathrm{O}$ of without egg shell, Thrusting radioactive waste in Baghdad after exposure to exporters, one source of beta rays, and we took the readings and the other source of gamma rays. the quantities used in the preparation of samples in Table 1. The samples left to harden at room temperature after leaving it for a period of time. Preparation of samples and their weights in 
addition to the thickness of the sample according to the table $1 \mathrm{In}$ the Figure 3 and 4 We observe the sampling stages in the laboratory In the Figure 5 Sample after completion.

Table 1. Quantities mixing samples and thickness of the four samples.

\begin{tabular}{llllll}
\hline sample & Polymer & Epoxy & FeSO $\mathbf{4} \cdot \mathbf{H H}_{\mathbf{2}} \mathrm{O}$ & Egg shell & $\begin{array}{l}\text { Sample } \\
\text { Thickness (cm) }\end{array}$ \\
\hline 1 & $90 \mathrm{gm}$ & $90 \mathrm{gm}$ & $10 \mathrm{gm}$ & $10 \mathrm{gm}$ & 0.8 \\
2 & $70 \mathrm{gm}$ & $70 \mathrm{gm}$ & $30 \mathrm{gm}$ & $30 \mathrm{gm}$ & 0.9 \\
3 & $75 \mathrm{gm}$ & $75 \mathrm{gm}$ & 0 & $50 \mathrm{gm}$ & 0.7 \\
4 & $75 \mathrm{gm}$ & $75 \mathrm{gm}$ & $50 \mathrm{gm}$ & 0 & 0.7 \\
\hline
\end{tabular}

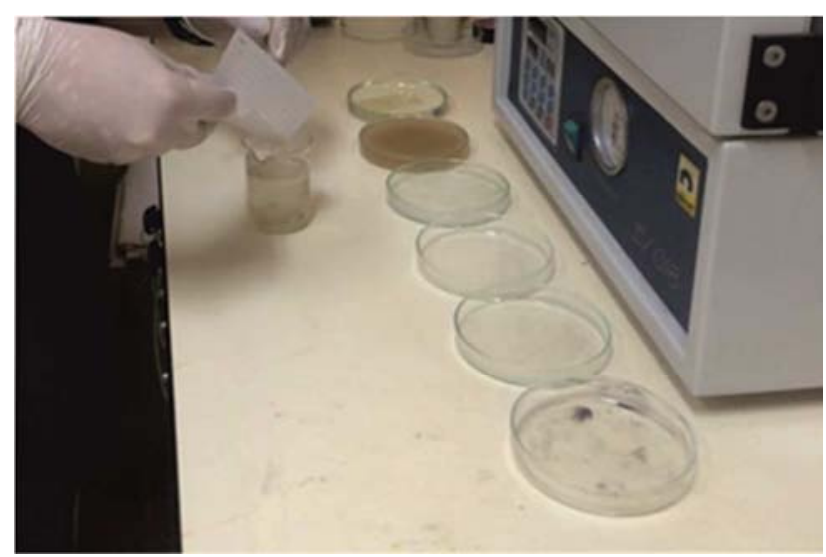

Figure 3. Stages of sample preparation in vitro.
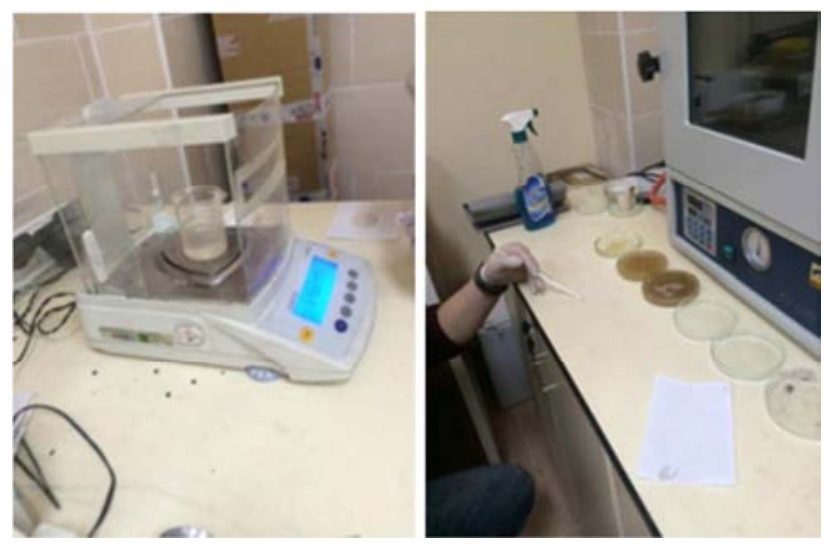

Figure 4. Stages of sample preparation in vitro.

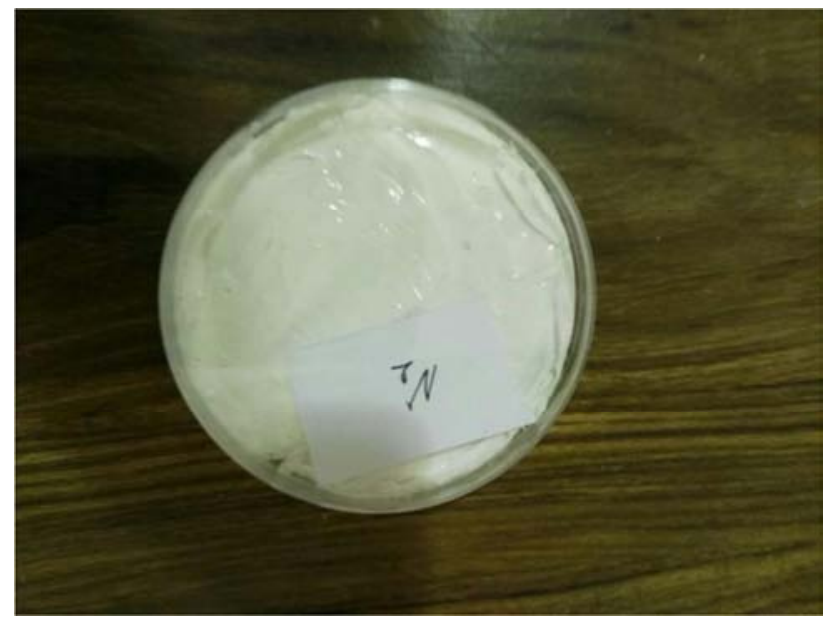

Figure 5. Sample after completion of preparation.

\section{Detector Inspector EXP}

With the development of technology and the emergence of new devices, sophisticated and compact. Detector Inspector EXP the use of small devices to detect alpha radiation, beta particles and gamma rays. Available in Detector Inspector EXP. the most performance, lightweight and easy to use Detector Inspector EXP was designed specifically for workers working in difficult places. It is easy to carry by hand and has a distinct sensitivity to measure and sense levels of alpha, beta particles, gamma rays, and X-rays. (Show). Detector RAP-RS2 probe - exterior Halogen extinguish, without compensation Cloud is unusual with the mica port 1.4-2.0 mg / cm2 Effective port diameter is $45 \mathrm{~mm}$ (1.75 N.). (The Ranger Exp) was used in the measurement As shown in Figure 6.

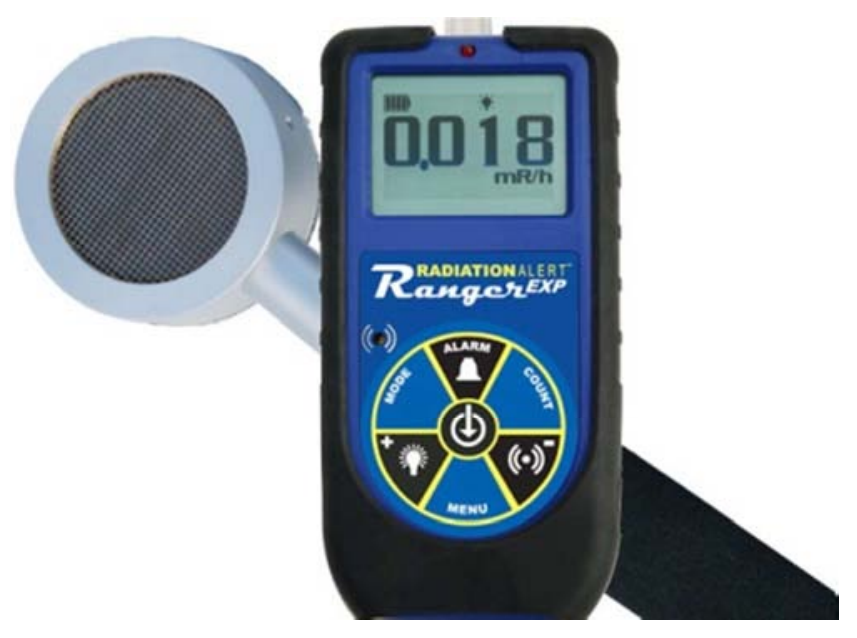

Figure 6. Scale Detector Inspector EXP

\section{Energy Sensitivity}

Alpha particles are detected as less to $2 \mathrm{MeV}$, The Beta particles are detected as less to $16 \mathrm{MeV}$, The typical efficiency of detection in $1 \mathrm{MeV}$ is approximately $25 \%$, Gamma rays are detected as less to $10 \mathrm{KeV}$, Through Detection port $3340 \mathrm{CPM} / \mathrm{mR} / \mathrm{hr}\left({ }^{137} \mathrm{Cs}\right)$ at the smallest Detection levels $125 \mathrm{I}$ is $02 \mu \mathrm{Ci}$ in connection. [21].

Built-In Efficiencies

Sulfur $\left({ }^{35} \mathrm{~S}\right)$, Strontium $\left({ }^{90} \mathrm{Sr} / \mathrm{y}\right)$, Cesium $\left({ }^{137} \mathrm{Cs}\right)$, Phosphorus $\left({ }^{32} \mathrm{P}\right)$, Carbon $\left({ }^{14} \mathrm{C}\right)$, Iodine $\left({ }^{131} \mathrm{I}\right)$, Cobalt $\left({ }^{60} \mathrm{Co}\right)$, and Alpha

Effectiveness

1) Cesium $\left({ }^{137} \mathrm{Cs}\right)$.

2) Iodine $\left({ }^{131} \mathrm{I}\right)$.

3) Strontium $\left({ }^{90} \mathrm{Sr} / \mathrm{y}\right)$.

4) Sulfur $\left({ }^{35} \mathrm{~S}\right)$.

5) Phosphorus $\left({ }^{32} \mathrm{P}\right)$.

6) Carbon $\left({ }^{14} \mathrm{C}\right)$.

7) Cobalt $\left({ }^{60} \mathrm{Co}\right)$

8) Alpha.

Sources of radiation

Radiation sources were used in Table 2 below to calculate shielding ratios in this research. 
Table 2. Radiation sources are used to draw conclusions.

\begin{tabular}{llll}
\hline Radiation & Source & Energy (keV) & activity \\
\hline Gamma rays & ${ }^{137} \mathrm{Cs}$ & 662 & 0.970 \\
Beta particles & ${ }^{90} \mathrm{Sr}$ & 546 & 0.1 \\
\hline
\end{tabular}

\section{Results and Discussion}

The results were prepared by the Exposor Exp and were prepared in the laboratories of the Department of radioactive waste management and treatment in Baghdad. Where radioactive sources were radioactive cesium and radioactive cobalt in contact with the samples, and the reagent would take (10) readings within a specified time. See Table 3 and Figure 7 for gamma readings, and see Table 4 and Figure 8 readings Beta readings.

Table 3. Readings of ${ }^{137}$ Cs source of gamma rays before and after contact.

\begin{tabular}{lllll}
\hline Before contact & sample(1) & sample(2) & sample(3) & sample(4) \\
\hline 8.930 & 0.177 & 0.143 & 0.148 & 0.055 \\
8.849 & 0.176 & 0.142 & 0.146 & 0.058 \\
8.756 & 0.173 & 0.136 & 0.145 & 0.062 \\
8.590 & 0.172 & 0.135 & 0.136 & 0.063 \\
8.590 & 0.170 & 0.134 & 0.122 & 0.068 \\
8.470 & 0.169 & 0.115 & 0.111 & 0.067 \\
8.384 & 0.131 & 0.101 & 0.083 & 0.071 \\
8.317 & 0.118 & 0.089 & 0.070 & 0.074 \\
8.284 & 0.102 & 0.073 & 0.065 & 0.070 \\
8.277 & 0.085 & 0.043 & 0.032 & 0.074 \\
\hline
\end{tabular}

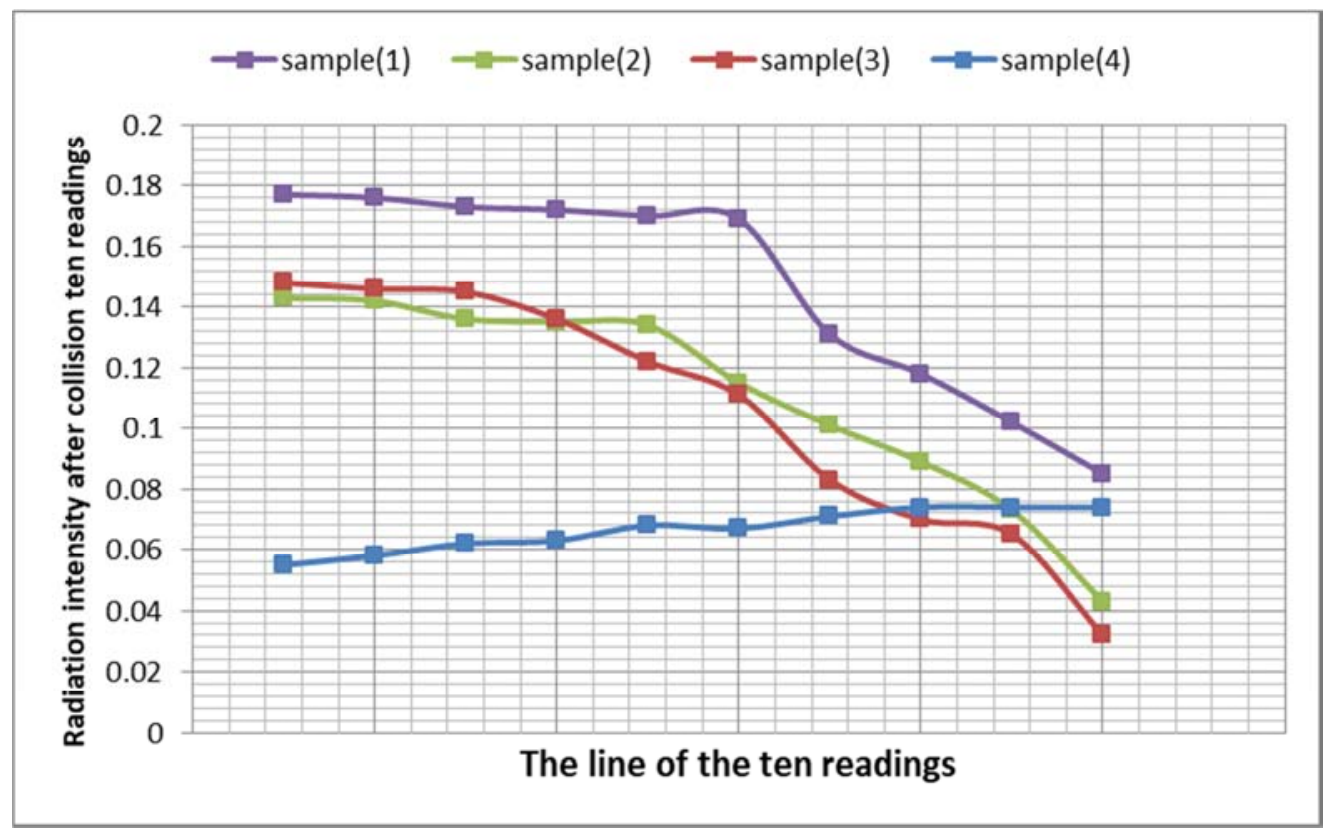

Figure 7. Readings of ${ }^{137}$ Cs source of gamma rays after contact The line of the ten readings.

Table 4. Readings of the ${ }^{90} \mathrm{Sr}$ radiator emitted for beta before and after contact.

\begin{tabular}{lllll}
\hline Before contact & sample(1) & sample(2) & sample(3) & sample(4) \\
\hline 32.49 & 0.017 & 0.016 & 0.016 & 0.014 \\
32.33 & 0.016 & 0.015 & 0.014 & 0.015 \\
31.90 & 0.014 & 0.014 & 0.017 & 0.016 \\
30.90 & 0.015 & 0.017 & 0.015 & 0.014 \\
30.84 & 0.016 & 0.016 & 0.016 & 0.016 \\
30.77 & 0.010 & 0.015 & 0.015 & 0.013 \\
30.73 & 0.014 & 0.016 & 0.014 & 0.014 \\
30.69 & 0.015 & 0.017 & 0.017 & 0.020 \\
30.56 & 0.016 & 0.015 & 0.015 & 0.017 \\
30.16 & 0.017 & 0.014 & 0.016 & 0.019 \\
\hline
\end{tabular}




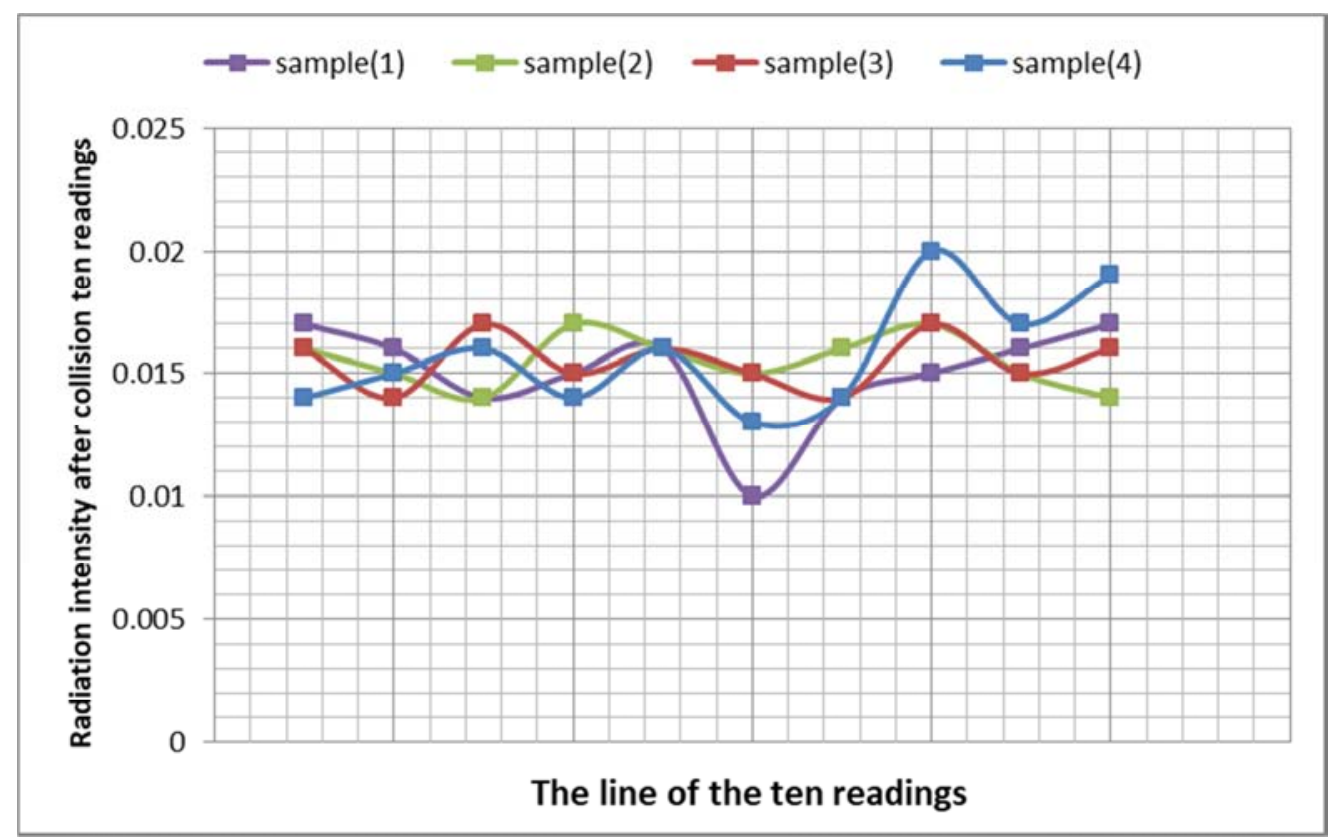

Figure 8. Readings of the ${ }^{90} \mathrm{Sr}$ radiation emitted for betta after contact The line of the ten readings.

\section{Discussion}

The first and second samples, with $100 \%$ weight of polymer and epoxy with $\mathrm{FeSO}_{4} \cdot 7 \mathrm{H}_{2} \mathrm{O}$ and egg shell, the attenuation ratio increased. In the third sample, the attenuation coefficient increased by a very large percentage. The fourth sample is only $\mathrm{FeSO}_{4} \cdot 7 \mathrm{H}_{2} \mathrm{O}$ with epoxy and polymerase the best samples. Better than the remaining samples in the shielding of gamma rays As in the Figure 9 below.

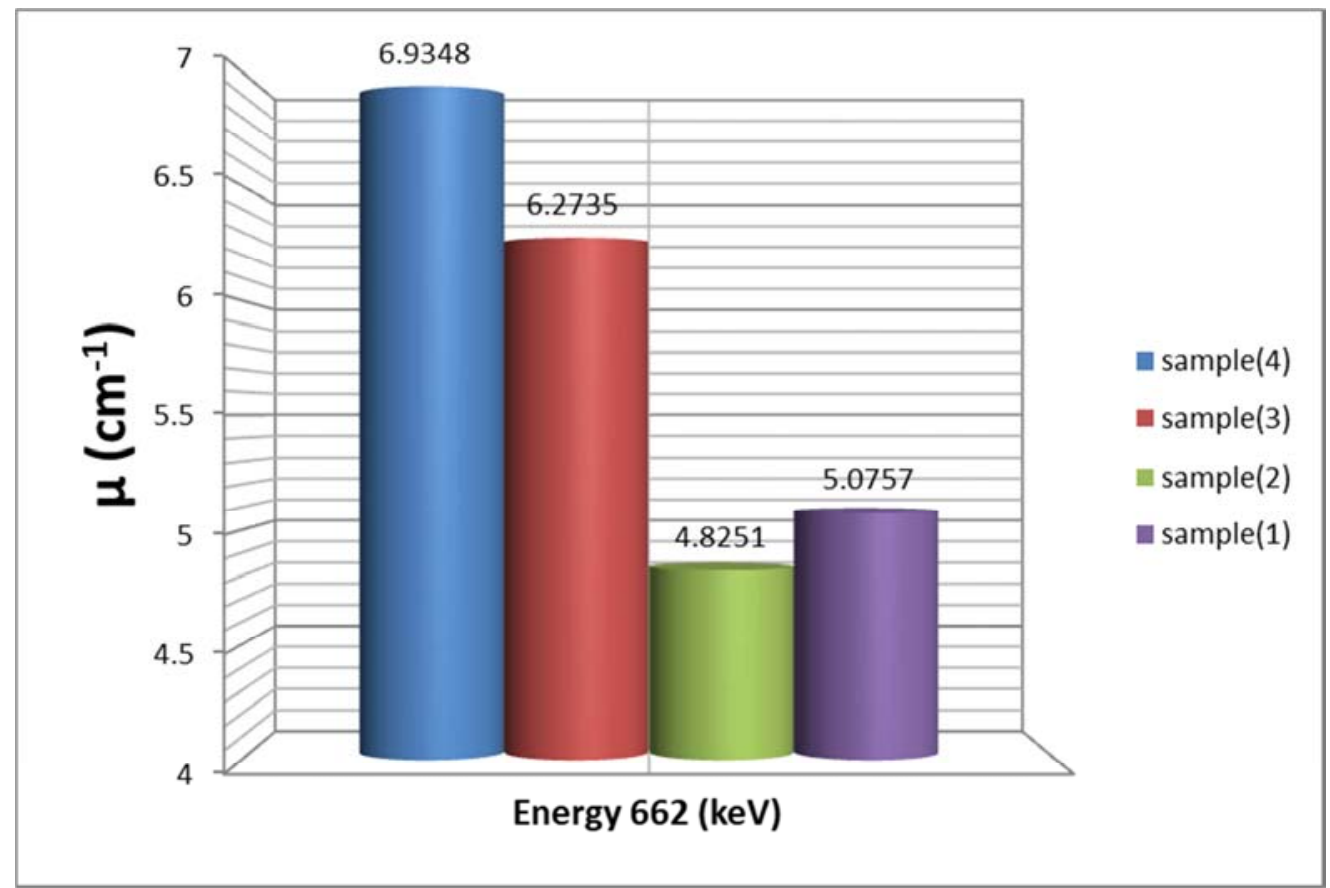

Figure 9. Diagram of the gamma attenuation coefficient on the four samples.

In the first and second samples, the linear attenuation coefficient will increase as the amount of egg shell and Melanterite increases by $100 \%$. The increase of these materials by specific percentages has a significant effect on beta ray shielding. For the third sample, the egg shell with epoxy and polymer only And the percentage of weight $100 \%$ increased the attenuation coefficient by a large percentage and we observed in this sample a significant impact on the attenuation coefficient and this is a good observation that this material is natural and also available in nature and easy to endoscopy, the latter sample was only with epoxy and polymer and $\mathrm{FeSO}_{4} .7 \mathrm{H}_{2} \mathrm{O}$ noted that the attenuation coefficient increased by Ratio is greater than the third sample As in the Figure 10 below. 


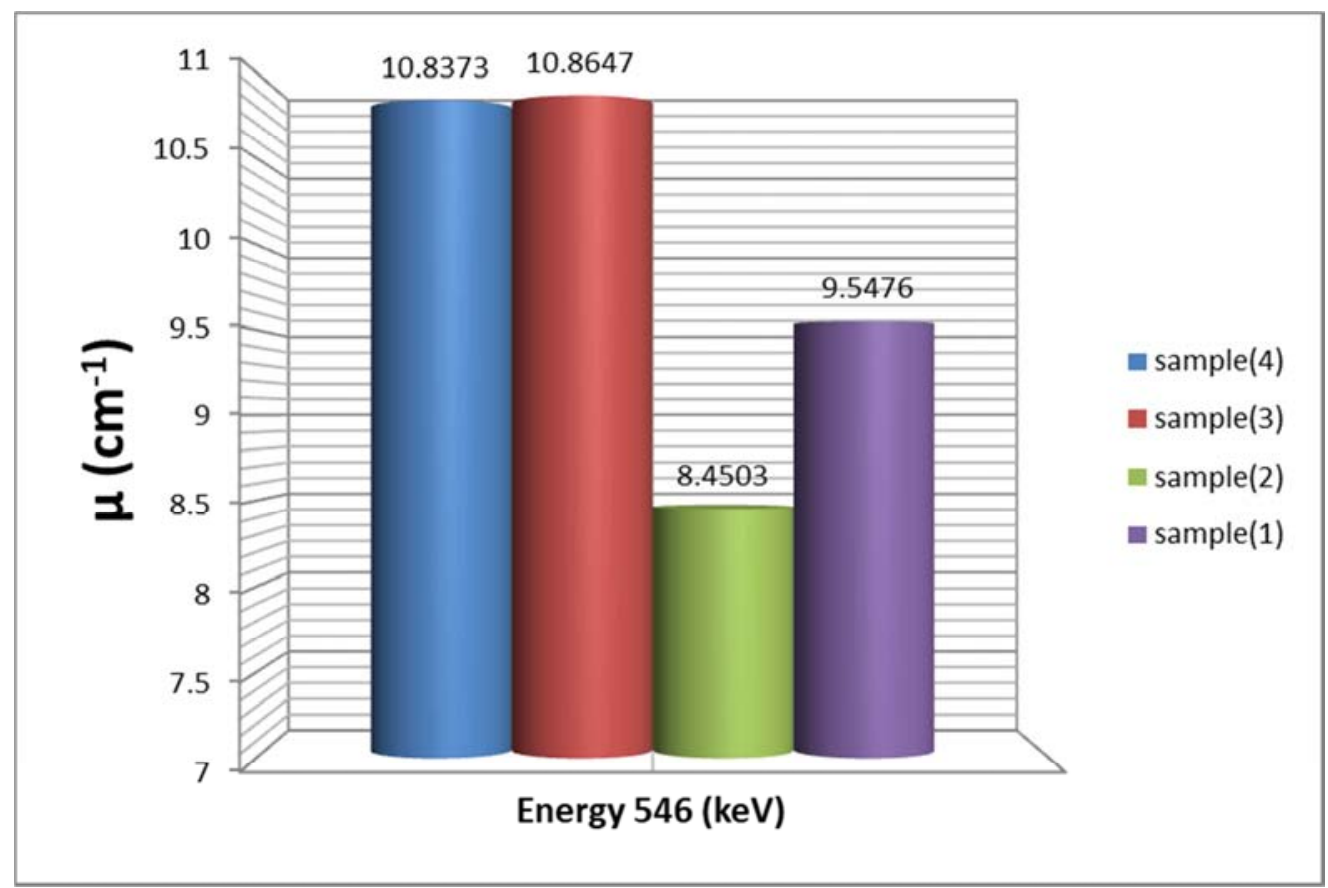

Figure 10. Diagram of the beta attenuation coefficient on the four samples.

\section{Conclusion}

The weights of natural additives and chemical compounds with polymeric backing material observed that $\mathrm{FeSO}_{4} \cdot 7 \mathrm{H}_{2} \mathrm{O}$ is very good as a shield of beta and gamma as well. And also the material of egg shells this natural and available material, which protects a small creature from the beginning of its composition to be a full chick, fully protected from various radiation and hazardous pollutants that can be exposed to it. this experience proved that the egg shell is more effective and better than the $\mathrm{FeSO}_{4} \cdot 7 \mathrm{H}_{2} \mathrm{O}$, New discovery enhances the eye of humanity on the exploitation available and benefit from what is available in nature and organic materials and vitality. The constantly and extensively research organic and bioactive substances to create protective shields from ionizing radiation.

\section{References}

[1] Townsend, Peter. The dark side of technology. Oxford University Press, 2017.

[2] Braccini, Saverio. "Compact Medical Cyclotrons and their use for Radioisotope Production and Multi-disciplinary Research." Hospital 200.250 (2017): 10-3.

[3] Al-Sarray, E., et al. "Radiation Shielding Properties of Some Composite Panel." Acta Physica Polonica, A. 132.3 (2017).

[4] AL-Sarray, E., and Ali Saleh Jabbar. "Shield against beta radiation and gamma of polymer compounds, Melanterite and Eggshells." Journal Port Science Research (2018). DOI: 10.13140/RG.2.2.12028.03208.

[5] Menard, K. P., and N. R. Menard. "Encyclopedia of polymer science \& technology." (2015).
[6] Jin, Fan-Long, Xiang Li, and Soo-Jin Park. "Synthesis and application of epoxy resins: A review." Journal of Industrial and Engineering Chemistry 29 (2015): 1-11.

[7] Mindat.org is the online mineral and locality database, containing information on minerals, rocks, meteorites, and more. www.mindat.org

[8] Mittal, Alok, et al. "Applications of egg shell and egg shell membrane as adsorbents: a review." Journal of Molecular Liquids 223 (2016): 376-387.

[9] Brown, Lesley (1993). The New shorter Oxford English dictionary on historical principles. Oxford [Eng.]: Clarendon. ISBN 0-19-861271-0.

[10] Ralph, Jolyon; Chautitle, Ida. "Szomolnokite". Mindat.org. Retrieved 2014-08-03.

[11] "Rozenite Mineral Data". Retrieved 2014-08-03.

[12] "Siderotil Mineral Data". Retrieved 2014-08-03.

[13] "Ferrohexahydrite Mineral Data". Retrieved 2014-08-03.

[14] "Melanterite Mineral Data". Retrieved 2014-08-03.

[15] Hunton, Peter. "Research on eggshell structure and quality: An historical overview." Revista Brasileira de Ciência Avícola 7.2 (2005): 67-71.

[16] Orłowski, Grzegorz, et al. "Residues of chromium, nickel, cadmium and lead in Rook Corvus frugilegus eggshells from urban and rural areas of Poland." Science of the Total Environment 490 (2014): 1057-1064.

[17] Hecht J: Eggshells break into collagen market. New Scientist 1999, 161:6-6.

[18] Daengprok W, Garnjanagoonchorn W, Mine Y: Fermented pork sausage fortified with commercial or hen eggshell calcium lactate. Meat Science 2002, 62:199-204. 
[19] Wei Z; Li B; Xu C (2009). "Application of waste eggshell as low-cost solid catalyst for biodiesel production". Bioresource Technology. 100 (11): 2883-2885. doi:10.1016/j.biortech.2008.12.039.

[20] Ćurković, Lidija, et al. "From eggshells biowaste to hydroxyapatite biomaterial." Materialwissenschaft und Werkstofftechnik 48.8 (2017): 797-802.
[21] Exhibition (INDIANA CONVENTION CENTER \& LUCAS OIL STADIUM). (accessed April 2017). http://events.pennwell.com/FDIC2017/public/eBooth.aspx?In dexInList $=566 \&$ FromPage $=$ Exhibitors.aspx\&ParentBoothID $=$ $\&$ ListByBooth $=$ true $\&$ BoothID $=492854$ 